\title{
Ichnofossils from the Middle Bhuban Unit, Bhuban Formation of Pachhy Lokah near Maubawk, Siaha District, Mizoram, India
}

\author{
Elita Rose ${ }^{* 1}$, Lalchawimawiii ${ }^{1}$, A. Lalrammuana ${ }^{1}$, J. Malsawma ${ }^{1}$, Paul Lalnuntluanga ${ }^{1}$, and \\ R. P. Tiwari ${ }^{2}$
}

${ }^{1}$ Deparment of Geology, Mizoram University, Tanhril, Aizawl, 796001, India

${ }^{2}$ Vice Chancellor, Central University of Punjab, Bathinda, 15100, India

\begin{abstract}
Trace fossils provide us with indirect evidence of life in the past, such as the foot prints, tracks, burrows, borings and feces left behind by animals rather than the preserved remains of the body of the actual animal itself. These imprints give palaeontologies clues with evidence of the activities of ancient animals, something body fossils simply cannot do. The Middle Bhuban rocks of Bhuban Formation are well exposed in the study area comprising sandstone, siltstone, shales and their admixtures. The grey sandstone unit exposed at Pachhy Lokah, Siaha is marked by well-preserved trace fossils comprising a total of eleven ichnospecies belonging to seven ichnogenera have been identified, namely: Katbergia isp., Laevicyclus mongraensis, Ophiomorpha nodosa, Ophiomorpha borneensis, Palaeophycus alternatus, Palaeophycus heberti, Palaeophycus striatus, Phycodes curvipalmatum, Psilonichnus upsilon, Psilonichnus isp. and Skolithos verticalis. Thus, it can be inferred from the presence of ichnofossils, that the studied successions of Bhuban Formation, Surma Group of Mizoram were deposited under sandy shifting substrate and high energy conditions in foreshore to unconsolidated, poorly sorted soft substrate and low energy condition in shoreface/offshore zone of shallow marine environment with occasion storm events.
\end{abstract}

Keywords: Bhuban Formation, domoichnia, shale, Ichnofossils, surma group.

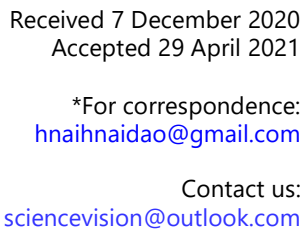

sciencevision@outlook.com

\section{Introduction}

Pachhy Lokah is located between Kawlchaw and Maubawk, the Middle Bhuban Formation is represented by an uninterrupted succession of rocks of about $80 \mathrm{~m}$ thickness in this area. The rock types exposed in the study area are thickly bedded sandstone, silty-sandstone and with alternating thinly bedded shales. In some cases, shales are intercalated with sandstone. The sandstones are grey to brown in colour, fine to medium grained, compact, relatively hard with cementing materials of varying composition, viz., calcareous, arenaceous, ferruginous etc. The trend of the rock formations here is roughly N-S with dip $20^{\circ}$ due east. The study area falls under the survey of India topo sheet no. $84 \mathrm{~A} / 10$ and lies between latitude $24^{\circ} 40^{\prime} 30^{\prime \prime}$ and $24^{\circ}$ $40^{\prime} 50^{\prime \prime} \mathrm{N}$ and longitude $92^{\circ} 40^{\prime} 30^{\prime \prime}$ and $92^{\circ} 42^{\prime} 48^{\prime \prime} \mathrm{E}$, about $22 \mathrm{~km}$ south of the Siaha town, Aizawl, Mizoram.

The objective of the proposed study area is to carry out the palaeoecologic and 


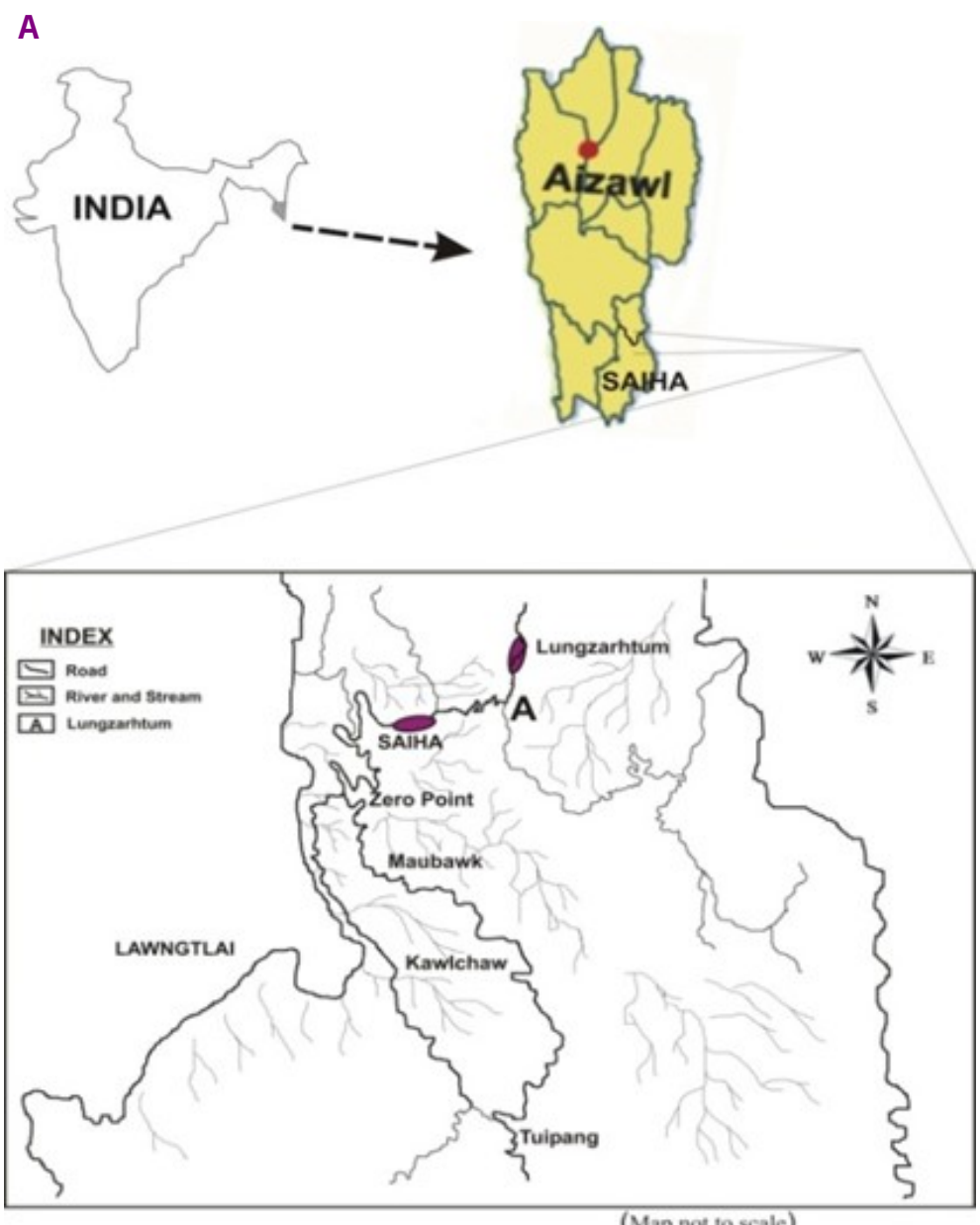

(Map not to scale)

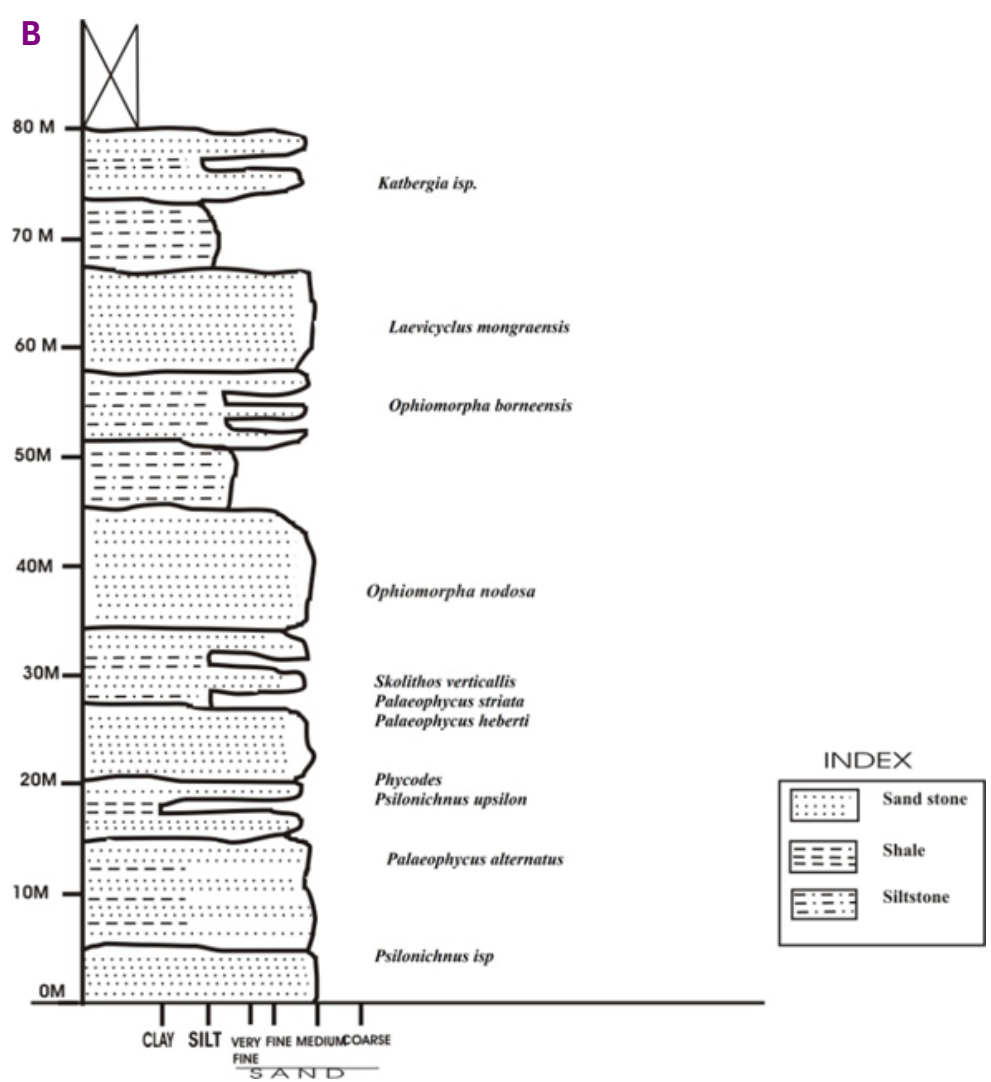

Figure 1 | Location map of the study area (A) and litho-column of the fossil locality (B). 
paleoenvironmental significance of the documented trace fossil assemblage and systematically describe the collected trace fossils.

\section{Geological setting}

Geologically, Mizoram is a part of the TripuraMizoram Accretionary belt of Cenozoic age. It is considered to be the southern extension of the Surma basin. The entire sedimentary succession of Mizoram consists of arhythmic alternation of arenaceous and argillaceous rocks with a thickness of about 8000 meters. Main rock types exposed in this area are sandstone, siltstone, shale, and their admixture of varying proportions.

The Tertiary rocks of Mizoram have been grouped sequentially into Barail, Surma and Tipam Groups in ascending order of their age respectively. The Surma Group is divisible into a lower Bhuban Formation and an upper Boka Bil Formation. Bhuban Formation is further divisible into lower, middle and upper Bhuban Units.

\section{Materials and Methods}

The fossils were photographed and collected to study their systematic description with the help of material available in the repository in the Department of Geology, Mizoram University and the published available literature. The rock types, their vertical and lateral continuity and facies variation were studied in each bed and generalized as a lithocolumn. Data regarding the distribution pattern of fossils in the sediments such as orientation, state of preservation, their association are also collected in order to decipher the depositional environment. Dimensions are taken in millimeters.

\section{Results}

\section{Systematic description of ichnofossils}

A total of eleven ichnospecies belonging to seven ichnogenera have been identified. Most specimens figured in this paper are housed in the Geology Department of Mizoram University.

Ichnospecies: Katbergia isp.

(Plate 1, Fig. a)

Material: Field photograph of grey coloured sandstone with a burrow.

Description: Long, cylindrical, unlined, straight to gently curved, non-branching burrow with an apical chamber; inclined at angles of approximately 50 degrees. Burrow penetrates $10 \mathrm{~cm}$ in down ward direction, diameter of the burrow is variable throughout the length, and maximum burrow diameter of $2.9 \mathrm{~cm}$ is observed at the apical chamber and gradually decreasing downward thereafter. Other than the apical chamber part, burrow represents fine concentric structures. Burrow fill is identical to host sediments.

Remarks: This ichnospecies is similar to the Katbergia carltonichnus Gastaldo and Rolerson but differs in the position of the living chamber. The present specimen shows an apical chamber instead of the terminal chamber. Retallack and co-workers ${ }^{1}$ identified them as Macanopsis and used the burrows to define several Triassic palaeosols interpreted to represent river or lakeside environments. Potential trace makers include crab, spiders, beetles, and shrimps. ${ }^{1,2}$ The type specimen, Macanopsis pagueyi was described by Macsotay ${ }^{3}$ as a straight-to-curved tube with a circular-to-oval cross-section ranging between 10 and $40 \mathrm{~mm}$ in diameter. This marine burrow enters the substrate at an angle of 90 degrees and slowly curves in a J-shape, ending in an enlarged chamber. (1971)

Ichnospecies: Laevicyclus mongraensis Verma (Plate 1, Fig. f)

Material: Field photograph of grey coloured sandstone with a burrow and brown coloured sandstone with a burrow.

Description: Endichnical, full relief, vertical cylindrical body making right angle to bedding plane and appear as regular concentric circles. The outer ring is thick and prominent and encloses the inner tube. The burrow shows maximum outer diameter of $6 \mathrm{~cm}$, the central tube is large and prominent with diameter of $2.6 \mathrm{~cm}$. The burrow is half cut and exposed due to the erosional factor. The sediment fill is identical to surrounding.

Remarks: Diameter of central shaft and scraping circles show close similarities with Laevicyclusmongraensis. ${ }^{4}$

Ichnogenus: Ophiomorpha Lundgren (1891) (1965)

Ichnospecies: Ophiomorpha borneensis Keij

(Plate 1, Fig. e)

Material: Field photograph of grey coloured sandstone with a burrow

Description: Full relief and endichnial burrows with long straight vertical shafts; lined packed with the bilobate pellets. Rare to scattered ovoid or single pellets are also found. Depth of the burrow is about $12 \mathrm{~cm}$ and diameter is $2.8 \mathrm{~mm}$. Burrow tubes have thick wall formed of ferruginous and argillaceous 


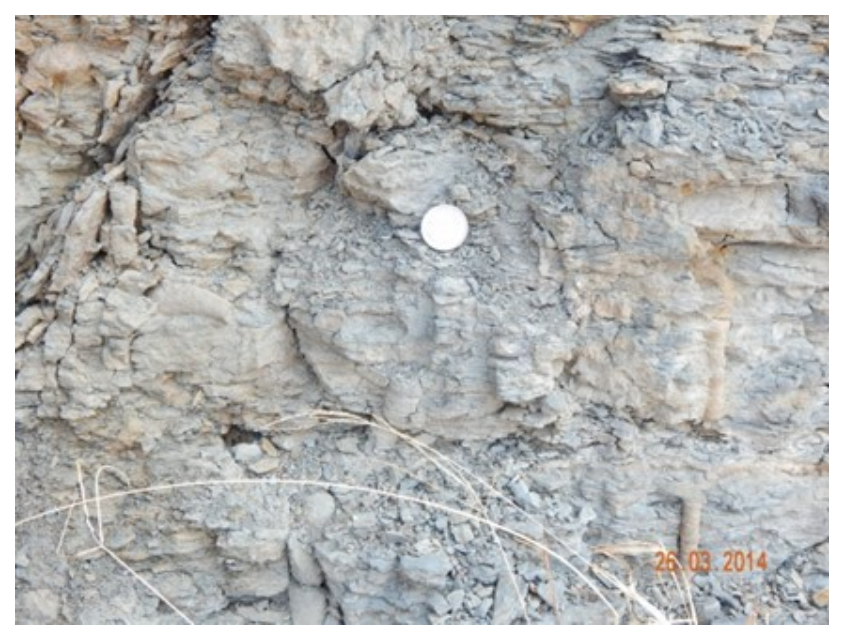

A

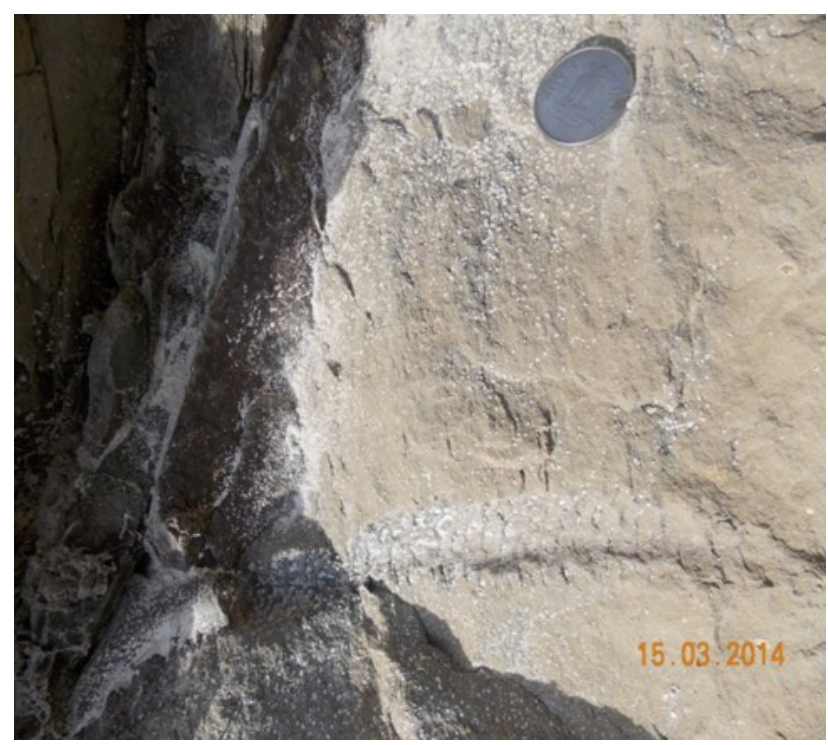

C

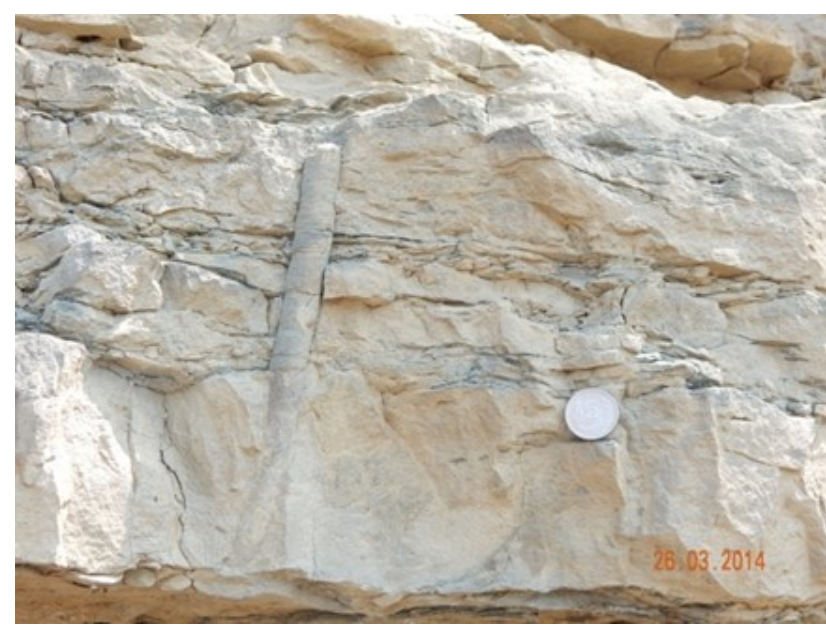

E

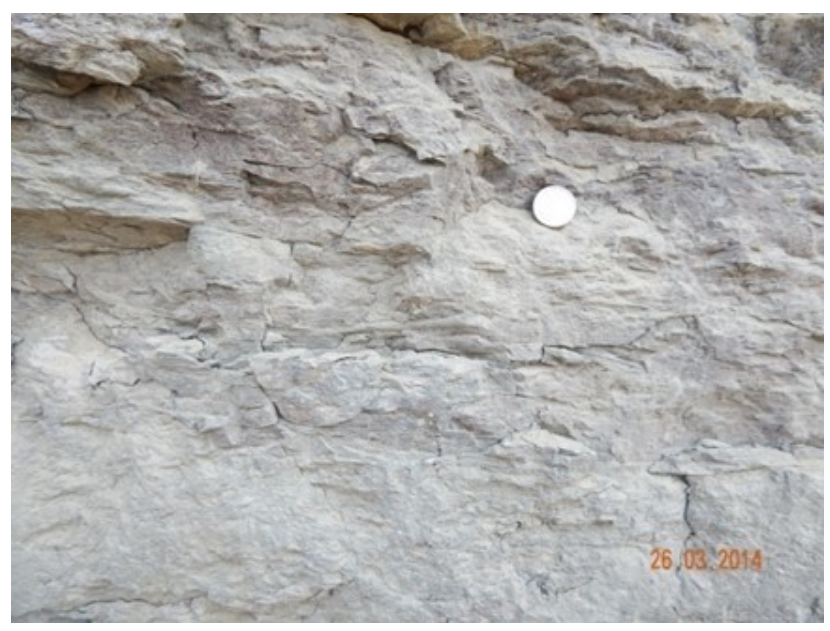

B

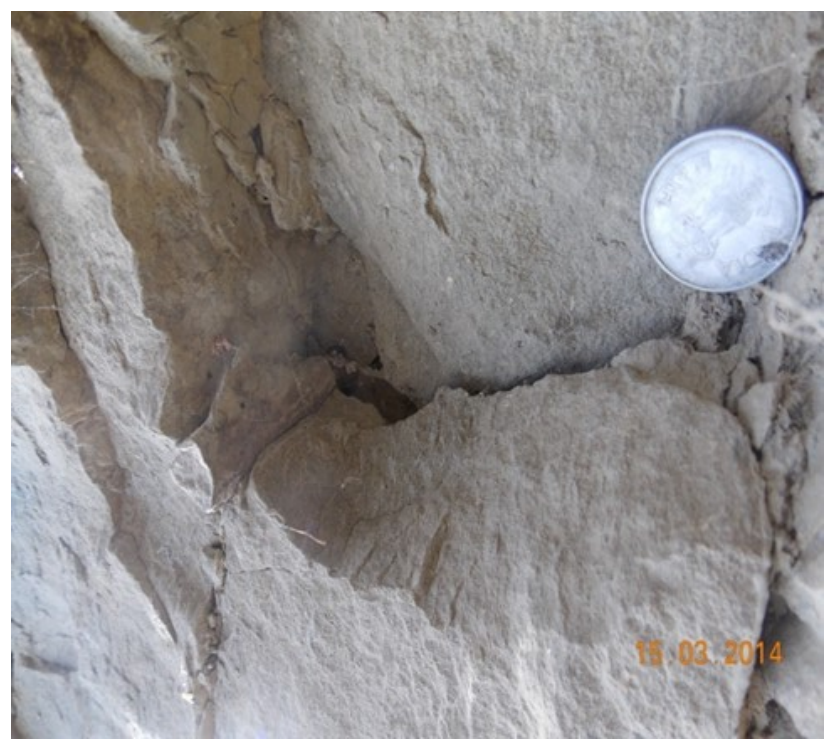

D

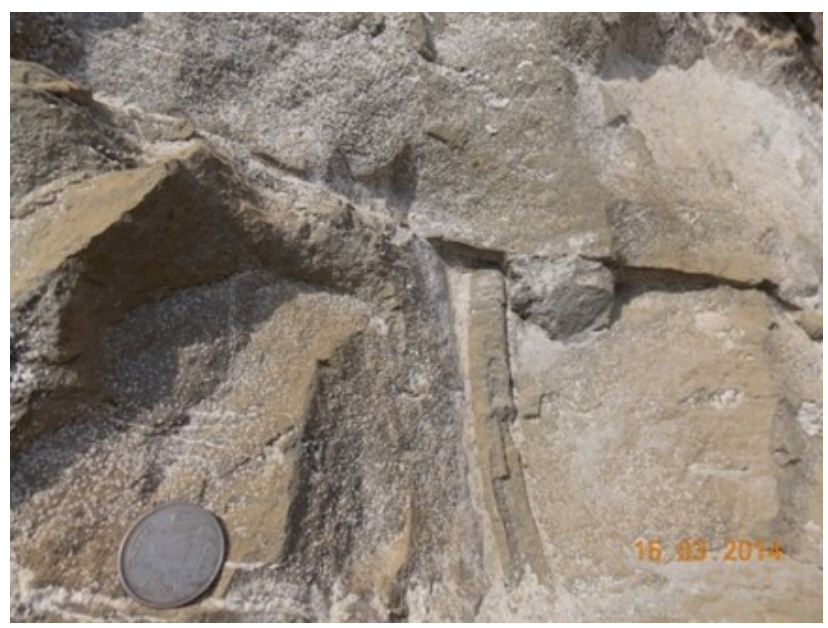

$\mathbf{F}$

Plate 1 | (A) Katbergia isp. (B) Palaeophycus alternatus (C) Ophiomorpha nodosa (D) Palaeophycus heberti (E) Ophiomorpha borneensis (F) Laevicyclus mongraensis 


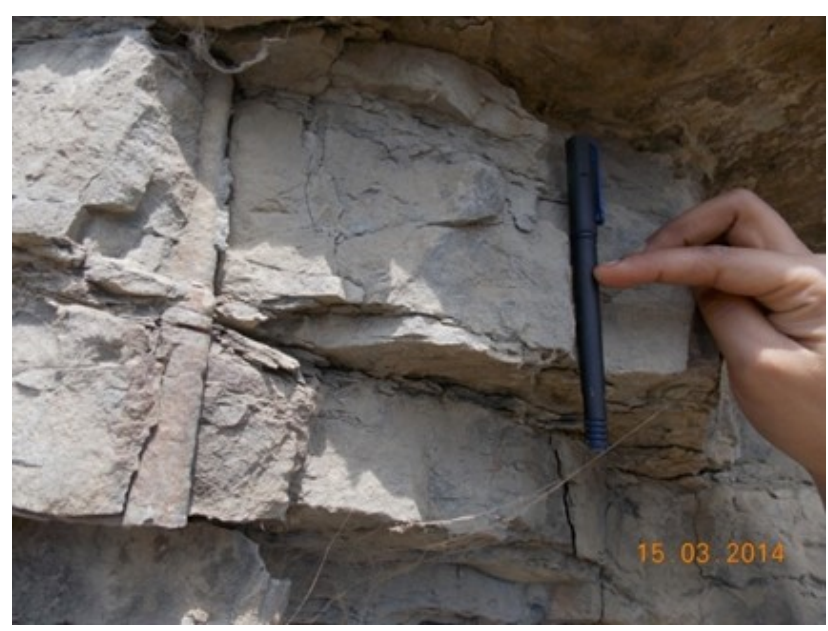

G

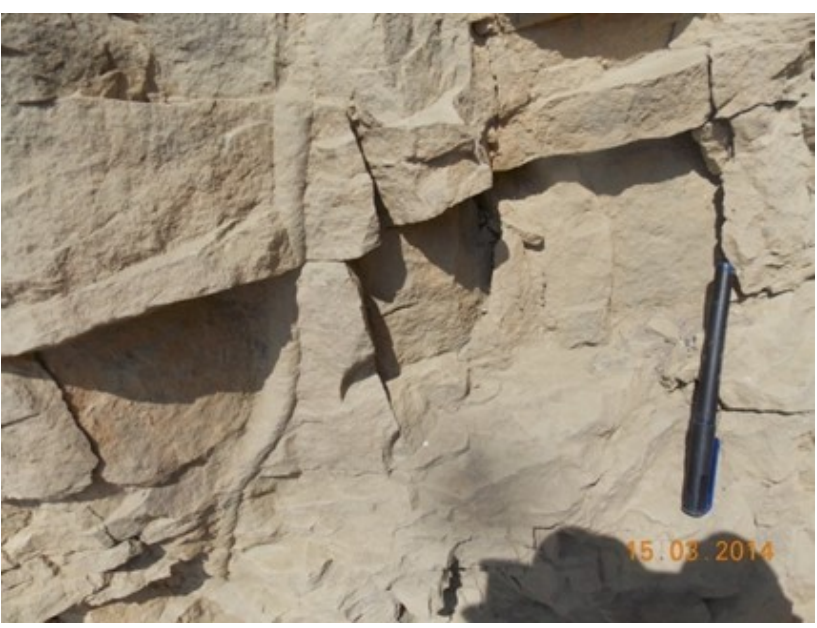

I

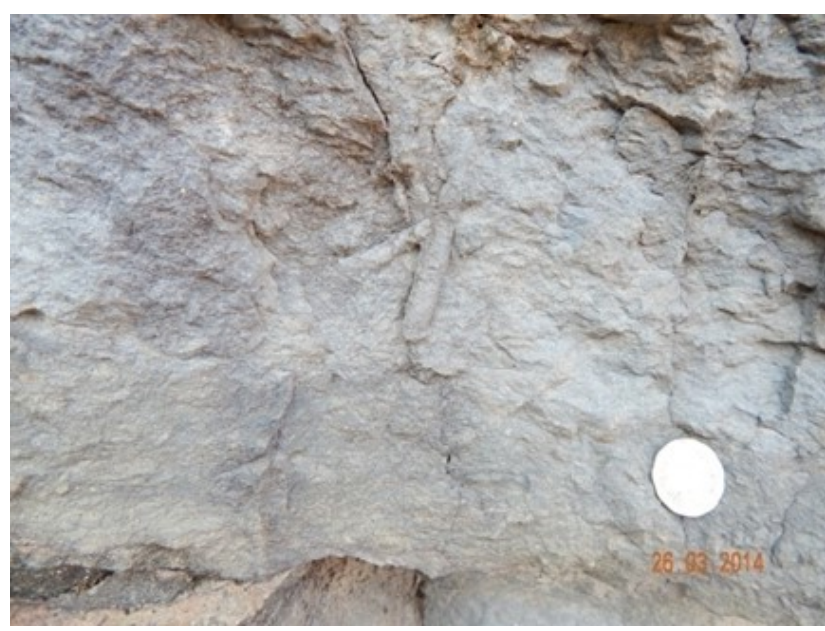

H

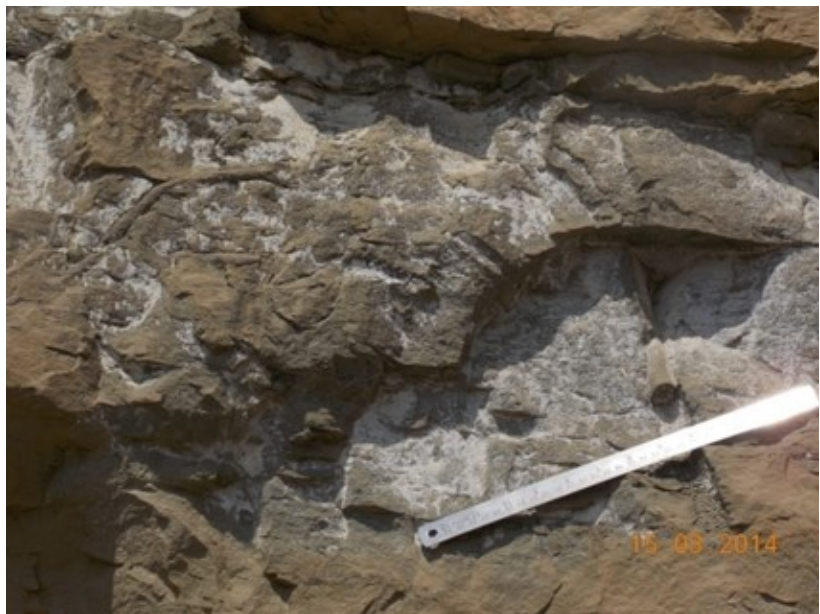

J

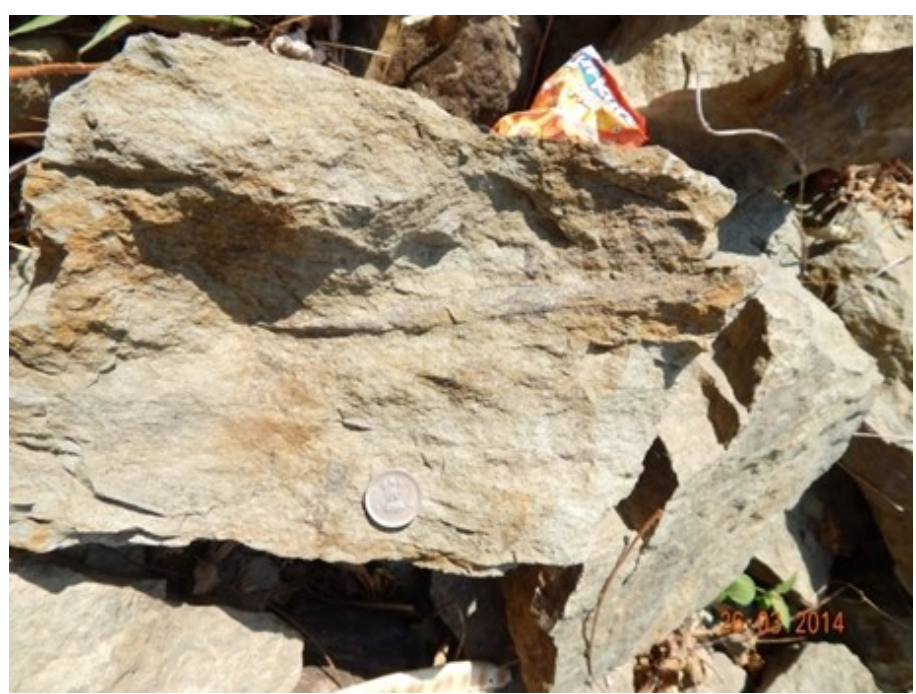

K

Plate 2 | (G) Skolithos verticalis (H) Psilonichnus upsilon (I) Psilonichnusisp (J) Phycodes curvipalmatum (K) Palaeophycus striatus 
material with smooth interior surfaces and distinctly irregular rugose exterior surface. The burrow fill is different than the surrounding sediment.

Remarks: According to Frey and co-workers, ${ }^{5}$ the morphology of this form is like $O$. nodosa and $O$. irregularie which could be genetically related. Fursich $^{6}$ regarded $O$. borneensis to be synonym of Spongiliomorpha saxonica but failed to consider the bilobate pellets. (1891)

Ichnospecies: Ophiomorpha nodosa Lundgren

$$
\text { (Plate1, Fig. c) }
$$

Material: Field photograph of brown coloured sandstone with a burrow and grey coloured sandstone with a burrow

Description: Endichnial, lined, unbranched, vertical to inclined burrows. The walls of the burrows consist of regularly distributed discoid pellets. The depths of the burrows are ranges from 30 to $36 \mathrm{~cm}$ in observed specimens but it also penetrates to more depth. Diameter of the burrow and pellets ranges from 1.4 to $2.7 \mathrm{~cm}$ and 0.3 to $0.4 \mathrm{~cm}$ respectively. The burrow fill is same as the host rock but pellet lined structures consist of darker material (muddy clastic sediment) than the host sediment.

Remarks: The morphological characters of the present burrows are similar to $O$. nodosa Lundgren. Different ichnospecies of Ophiomorpha are differentiated on the basis of variations in burrow configuration, shape and distribution of the pellets. ${ }^{5,7,8}$

Ichnogenus: Palaeophycus Hall (1847)

Ichnospecies: Palaeophycus alternates Pemberton \& Frey (1982)

(Plate 1, Fig. b)

Material: Field photograph of grey coloured sandstone with a burrow.

Description: Hypichnial, full relief, slightly curved, thinly lined burrows encircled by thin ring like structures or distinctly placed annulations arranged serially on the burrows. The diameter of the burrow is constant being of $10 \mathrm{~mm}$ and length of the burrow is $40 \mathrm{~mm}$. The burrow fill is structureless and identical to the surrounding materials.

Remarks: The characteristic annulations occurring on the tubes support its recognition as $P$. alternatus. $^{9}$

Ichnospecies: Palaeophycus heberti Saporta (1872)
(Plate 1, Fig. d)

Material: 4 Field photographs of grey colour sandstone with a burrow.

Description: The present burrow is simple, straight to slightly curved, horizontal, smooth, nearly cylindrical, unbranched, and unornamented, thickly lined and circular in cross section. Diameter is more or less constant at $1.5 \mathrm{~cm}$ throughout the length of the burrow and length of the burrow is $12 \mathrm{~cm}$; the burrow is filled with the same sediment as the host rock.

Remarks: Studied specimen resembles closely well with the specimen of Palaeophycus heberti described and figured by Saporta. The thick wall lining distinguishes $P$. heberti from $P$. tubularis. Original specimens of Palaeophycus heberti were assigned initially to the Ichnogenus Siphonites, and their affinity with Palaeophycus was noted subsequently. Rajkonwar and co-workers. ${ }^{10}$ first recorded the ichnospecies from the Surma succession of Northeast India.

Ichnospecies: Palaeophycus striatus Hall (1852)

(Plate 2, Fig. k)

Material: Field photograph of buff coloured sandstone with full relief burrow.

Occurrence: Fine to medium grained and buff coloured sandstone bed (Bed no. 2), Middle Bhuban unit, Pachhy Lokah, Aizawl, Mizoram.

Description: Horizontal, straight, unbranched, full relief, thinly lined burrow with faint striations. The length of the burrow is $8 \mathrm{~cm}$ and diameter is 1.3 $\mathrm{cm}$. The burrow is fill is identical to the host rock.

Remarks: Rajkonwar and co-workers ${ }^{10}$ first recorded the ichnospecies from the Surma succession of Northeast India. This ichnospecies can differ from the other ichnospecies of Palaeophycus on the basis of having striations. Although striations are not clearly visible on the burrow due to erosion, the specimen is assigned to $P$. striatus considering the gross morphology. (1852)

Ichnospecies: Phycodes curvipalmatum Hall

(Plate 2, Fig. j)

Material: Field photograph of grey coloured silty -sandstone with two full relief burrows.

Description: Hypichnial, horizontal structures, consisting of two or three branches originated from the same point of a thick, slightly curved single stem. The branches are oval in cross section, with burrow 
diameters of 9 to $13 \mathrm{~mm}$, while the main tube is 12 $\mathrm{mm}$ and $14 \mathrm{~mm}$ in diameter. Burrows filled with very fine-grained sand which is identical with the host rock. The burrow occurs associated with Palaeophycus tubularis.

Remarks: Rajkonwar and co-workers ${ }^{10}$ first recorded the ichnospecies from the Surma succession of Northeast India. Phycodes reflects a variety of behavioural activities by the tracemaker , ${ }^{11}$ but two basic interpretations are: (i) a fodinichnion produced by an organism that systematically mining a nutrient-rich layer along a silt-mud surface, ${ }^{12}$ or (ii) a structure performed by an organism that burrowed outwards from a single point and then withdrew to a 'home-case' only to re-burrow outwards again in part the previously excavated tunnel. ${ }^{13,14}$ Phycodes are the characteristic trace fossil of the Cruziana ichnofacies and is mainly related with shallow water environments. ${ }^{14}$ It is commonly present at the base of centimeter-thick siltstone or silty sandstone beds within shales. ${ }^{15}$

Ichnogenus: Psilonichnus Fürsich (1981)

Ichnospecies: Psilonichnus upsilon Frey et al. (1984)

(Plate 2 Fig. h)

Material: Field photograph of grey coloured silty -sandstone with a full relief burrow and brown coloured sandstone with a burrow.

Description: The burrow exhibit steeply inclined Y-shaped structures in the upper part, grading downward with slightly curved shafts. One of the branched is more curved and smaller in diameter than the other. Diameter of the burrow varies from $1.5-2 \mathrm{~cm}$; angle of bifurcation is greater than $60^{\circ}$ and maximum observed depth is about $40 \mathrm{~cm}$.

Remarks: The present burrow shows similar morphological characters with Psilonichnus upsilon described by Rajgonwar and co-workers ${ }^{10}$ in all respect, and hence it has been placed under this ichnospecies. Frey and Pemberton ${ }^{16}$ identified the trace maker of $P$. upsilon as the extant ghost crab Ocypode Quadrata (Fabricus), as elucidated by polyester cast of J-shaped burrows from the lower backshore, Sapelo Island, Georgia.

Ichnospecies: Psilonichnus isp.

(Plate 2, Fig. i)

Material: Field photograph of grey coloured silty -sandstone with burrow.

Description: Isolated, vertical I-shaped, inclined, unbranched burrow having variable diameter. The burrow is slightly curved, lined with mud and passively filled; maximum observed length is $20 \mathrm{~cm}$ and diameters vary from 1.5 to $2.5 \mathrm{~cm}$.

Remarks: The isolated, vertical I-shaped, slightly curved, lined with mud nature of the present burrow resembles very well with the ichnogenus Psilonichnus in all respect, hence it has been placed under this ichnogenus. Rajkonwar and co-workers ${ }^{10}$ first recorded the ichnospecies from the Surma succession of Northeast India. Ichnospecies level identification was not attempted due to lack of sufficient data.

Ichnogenus: Skolithos Haldemann (1840)

Ichnospecies: Skolithos verticalis Hall (1843)

(Plate 2, Fig. g)

Material: Field photograph of grey coloured sandstones with a full relief burrow, and grey coloured silty sandstone with a burrow.

Description: Burrows are thick, stout, isolated, unbranched, cylindrical, lined and perpendicular to the bedding plane and widely spaced or as isolated form. The dimensions of the burrows vary in different burrow population and diameter varies from 1 to $1.5 \mathrm{~cm}$. The burrows are emplaced in fine grained sandy sediments and filled fine grained muddy sediments which are dark in colour and structure less.

Remarks: Skolithos verticalis differs from the Skolithos linearis by the filled materials, later is filled with muddy sediments. Skolithos verticalis has rough, annulated burrow walls. It is widely recognized in the shallow water, intertidal deposits ${ }^{17}$ and various shallow marine environments ${ }^{18,19}$ and is probably thought to be produced by annelids or phoronids. ${ }^{19}$

\section{Discussion}

The study area shows intercalated sequence of shale and sandstone, the proportion of the arenaceous sediments increases in the upward direction and consists of ethologically diverse group of trace fossils. These trace fossils largely constitute domichnia and fodichnia associations. Domichnia are the cylindrical dwelling burrows having strong wall lining of suspension feeders. ${ }^{20}$ The domichnia signatures are tangibly manifested in the recorded forms like Ophiomorpha borneensis, Laevicyclus mongraensis, and Skolithos. Fodichnia features are clearly evident in Palaeophycus heberti and Palaeophycus tubularis. The clastic sediments are characterized by the vertical ' $I$ ' and ' $Y$ ' shaped lined burrows like, Laevicyclus, Ophiomorpha and Skolithos. Skolithos is also dwelling burrows of suspension feeding organisms ${ }^{21}$ and were produced over a short period of time and the depositional 
environment was inhospitable to most life forms. This may be attributed to oxygen depletion, variable salinity, uneven rates of sediment accumulation or merely a newly-deposited biologically unconditioned substrate.

The trace fossils from this area represent Ophiomorpha assemblage, Palaeophycus assemblage, Phycodes assemblage and Skolithos assemblage. The Ophiomorpha assemblage is occurring in sandstone, silty-sandstone and alternate sandstone-shale beds of the section. This ichnoassemblage consist of Ophiomorpha Nodosa and Ophiomorpha borneensis with Laevicyclus mongraensis, Skolithos verticallis and Phycodes curvipalmatum. Ophiomorpha is a deposit and/or suspension feeder ${ }^{22,23}$ and its traces are found in the shallow water environment in siliceous and calcareous sedimentary facies of post-Paleozoic ages. $^{24,23}$ Laevicyclus mongraensis is a cylindrical dwelling burrow having strong wall of suspension feeder ${ }^{25}$ having domichnion affinity and is known to occur in shallow marine set-up. The Palaeophycus assemblage occurs in sandstone-shale alternating beds and characterized by semi-vagile and vagile, deposit feeder structures present in oxygenated conditions. $^{26}$ The assemblage consists of Palaeophycus striatus, Palaeophycus tubularis and other associated trace fossils are Ophiomorpha borneensis, Phycodes curvipalmatum and Skolithos verticallis. Palaeophycus is a eurybenthic faciescrossing form produced probably by polychaetes or annelids in well oxygenated environment with abundant sub-surface food. ${ }^{27}$ Phycodes assemblage is dominated by Phycodes curvipalmatum in association with Ophiomorpha borneensis, Palaeophycus tubularis.

Phycodes is a characteristic trace fossil of the Cruziana ichnofacies. It is commonly found in shallow marine environments. ${ }^{11}$ The Skolithos assemblage is present in parallel laminated siltysandstone beds associated with Ophiomorpha nodosa, suggests relatively moderate to high energy conditions and shifting substrate. The trace fossils associated with these assemblages belong to Skolithos ichnofacies, Cruziana ichnofacies and at places mixing of both Skoliths-Cruziana ichnofacies. Skolithos ichnofacies indicates sandy shifting substrate and high energy conditions in foreshore zone while the Cruziana ichnofacies indicate unconsolidated, poorly sorted soft substrate and low energy condition in the shoreface/offshore zone. Both Ophiomorpha and Skolithos are associated with environments characterized by frequent high-energy events, drastic changes in the sedimentation rate and erosion of surface sediments. ${ }^{28,14}$ Laevicyclus mongraensis is a cylindrical dwelling burrow having strong wall of suspension feeder and is known to occur in shallow marine environments. ${ }^{25}$ These ichnofossils suggests that the lower part of the Bhuban succession of Pacchyh Lokah section was deposited under high energy events and drastic changes in the sedimentation rate in the intertidal to subtidal environments. Together these ichnofacies indicate sandy shifting substrate and high energy conditions in foreshore to unconsolidated, poorly sorted soft substrate and low energy condition in shoreface/offshore zone of shallow marine environment for the deposition of the ichnoferous horizons of this section.

The highly bioturbated units are dominated by the cylindrical, branched, large sized three dimensional horizontal burrows of Palaeophycus. These horizontal biogenic structures indicate low wave and current energy condition in the subtidal environment. Palaeophycus are horizontal structures that occur below the sediment-sediment interface, suggesting unconsolidated substrate experiencing relatively moderate to low energy sub-tidal conditions. Psilonichnus indicates backshore marginal marine environment. ${ }^{29}$ It is also in support of change in the colonization pattern of benthic community.

Thus, it can be inferred that the studied successions of Bhuban Formation, Surma Group of Mizoram were deposited under sandy shifting substrate and high energy conditions in foreshore to unconsolidated, poorly sorted soft substrate and low energy condition in shoreface/offshore zone of shallow marine environment with occasion storm events.

\section{Conclusions}

The Bhuban Formation of Surma Group is very well exposed in Saiha district of Mizoram. A rich association of trace fossils in the Bhuban Formation of Mizoram is mainly found in sandstone, siltysandstone lithologies. A total of eleven ichnospecies under seven ichogenera were identified which are dominated by feeding burrows and trails namely, Katbergia isp., Laevicyclus mongraensis, Ophiomorpha nodosa, Ophiomorpha borneensis, Palaeophycus alternatus, Palaeophycus heberti, Palaeophycus striatus, Phycodes curvipalmatum, Psilonichnus upsilon, Psilonichnus isp. and Skolithos verticalis are described in the present paper. Ethologically the association represents domichnia and fodinichnia groups. Simpson ${ }^{20}$ mentioned existence of close affinity between fodichnia, domichnia and pasichnia. Fodichnia are feeding burrows of deposit feeders, excavated while in search of foods within the sediments or at the sediment surface, fodichnia may follow a complex behavioural pattern predominated by radial tubes. These conspicuous fodichnial feature is very clearly evidenced in the present ichno assemblage by Palaeophycus ichnospcies. Regarding domichnia, Simpson ${ }^{20}$ mentioned that these are cylindrical dwelling burrows having strong wall of suspension feeder. These domichnial signatures are tangibly 
manifested in the present ichno assemblage record of Ophiomorpha borneensis, Ophiomorpha nodosa and Skolithos.

The ichno-assemblage of the study area represent Skolithos and Cruziana ichnofacies. Cruziana ichnofacies may indicate a prevalence of shoreface and offshore sandy shore with high energy condition during deposition. The overall ichnological and sedimentological data suggest that the studied successions of Bhuban Formation, Surma Group of Mizoram were deposited under sandy shifting substrate and high energy conditions in foreshore to unconsolidated, poorly sorted soft substrate and low energy condition in shoreface/offshore zone of shallow marine environment with occasion storm events.

\section{Acknowledgement}

The authors are thankful to Prof. Shiva Kumar, Head, Department of Geology, Mizoram University, Aizawl, for extending support and for necessary facilities available in the Department for the completion of this study. Helps from Dr. C. Lalchhanhima, Prof. Jimmy Lalnunmawia, Dr. Shikhar Kumar and A. Lalrammuana in the Department are appreciated.

\section{References}

1. Retallack, G. J., Smith, R. M. H. \& Ward, P. D. (2003). Vertebrate extinction across PermianTriassic boundary in Karoo Basin, South Africa. Geological Society of America, Bulletin, 115, 11331152.

2. Smith, R. M. H. \& Botha, J. (2005). The recovery of terrestrial vertebrate diversity in the South African Karoo Basin after the end-Permian extinction. Comptes Rendus Palevol, 4, 555-568.

3. Macsotay, O. (1967). Huellas problemáticas y su valor paleoecológico en Venezuela. Geos Revista Venezolana de Ciencias de le Tiarra, 16, 7-79.

4. Verma, K. K. (1971). On the occurrence of some trace fossils in the Bagh Beds of Amba Dongar area, Gujarat State. Journal of the Indian Geological Association, 12, 37-40.

5. Frey, R. W., Howard, J. D. \& Pryor, W. A. (1978). Ophiomorpha: its morphologic taxonomic and environmental significance. Palaeogeography Palaeoclimatology Palaeoecology, 23, 199-229. https:// doi.org/10.1016/0031-0182(78)90094-9

6. Franz T. Fursich, (1973). A revision of the trace fossils Spongeliomorpha, Ophiomorpha and Thalassinoides. Neues Juhrbuch fur Geologie und Palaontology / Monatshefte, 1978, H, 12, 719-735.
7. Howard, J. D. \& Frey, R. W. (1984). Characteristic trace fossils in nearshore to offshore sequences, Upper Cretaceous of east-central Utah. Canadian Journal of Earth Sciences, 21, 200-219.

8. Uchman, A. (2001). Eocene flysch trace fossils from the Hecho Group of the Pyrenees, northern Spain. Beringeria, 28, 3-41.

9. Badve, R. M. (1987). A reassessment of stratigraphy of Bagh Beds Barwah area, Madhya Pradesh with description of trace fossils. Journal of the Geological Society of India , 30, 106-120.

10. Rajkonwar, C., Tiwari, R.P., \& Patel, S. J. (2013). Arenicoliteshelixus isp. nov. and associated ichnospecies from the Bhuban Formation, Surma Group (Lower-Middle Miocene) of Aizawl, Mizoram, India. Himalayan Geology, 34, 18-37.

11. Yaojun Han \& Ron K . Pickerill, (1994). Phycodes templus isp. nov. from the Lower Devonian of northwestern New Brunswick, eastern Canada. Atlantic Geology, March 1994, 30, 37-46.

12. Seilacher, A. (1955). Spuren und Fazies im Unterkambrium: in O. H. Schindewolf and A. Seilacher, Beitrage zur Kenntnis des Kambriums in der Salt Range (Pakistan). Akademie Der Wissenschaften Und Literatur Mainz, MathematischNaturwissenschaftliche Klase lib, Abhandlungen, no. 10, 11-143.

13. Marintsch, E. J. \& Finks, R. M. (1982). Lower Devonian ichnofacies at Highland Mills, New York and their gradual replacement across environmental gradients. Journal of Paleontology, 56, 1050-1078.

14. Singh, R. K, Rodriguez-Tovar F. J. \& Ibotombi, S. (2008). Trace fossils of the Upper Eocene-Lower Oligocene transition of the Manipur IndoMyanmar Ranges (Northeast India). Turkish Journal of Earth Sciences, 17, 821-834.

15. Mángano, M. G., Buatois, L. A. \& Guinea, F. M. (2005). Ichnology of the Alfarcito Member (Santa Rosita Formation) of northwestern Argentina: Animal-substrate interactions in a lower Paleozoic wave-dominated shallow sea. Ameghiniana, 42, 641-668.

16. Frey \& Pemberton, (1987). The Psilonichnus Ichnocoenose, and its relationship to adjacent marine and non-marine Ichnocoenoses along the Georgia coast 1. Bulletin of Candian Petroleum Geology, 35(3),333-357. https://doi.org/10.35767/ gscpgbull.35.3.333

17. Seilacher, A. (1967). Bathymetry of trace fossils. Marine Geology, 5, 413-428. https:// doi.org/10.1016/0025-3227(67)90051-5 
18. Fillion, D. \& Pickerill, R. K. (1990). Ichnology of the Upper Cambrian to Lower Ordovician Bell Island and Wabama groups of eastern Newfoundland, Canada. Palaeontographica Canadiana, 7, 1-119. http://www.worldcat.org/ oclc/23948494

19. Alpert, S. P. (1974). Systematic review of the genus Skolithos. Journal of Paleontology, 48, 661-669. https:// www.jstor.org/stable/1303217

20. Simpson, S. (1975). Classification of trace fossils. In: RW Frey (Ed) The Study of Trace Fossils. Springer-Verlag, New York, pp. 39-54. https:// doi.org/10.1007/978-3-642-65923-2_3

21. Patel, S.J., Desai, B.G. \& Shukla, R. (2009). Paleoecological significance of the trace fossils of Dhosa Oolite Member (Jumara Formation), Jhura dome, Mainland Kachchh, Western India. Journal of the Geological Society of India, 74, 601. https:// doi.org/10.1007/s12594-009-0175-9

22. Ekdale, A. A., (1992). Muckraking and mudslinging: the joys of deposit-feeding. In: Maples C.G. and West R.R. (eds), Trace Fossils Short Courses in Paleontology. The Paleontological Society, Knoxville, Tennessee, 5, 145-171.

23. Uchman, A. \& Gaździcki, A. (2006). New trace fossils from the La Meseta Formation (Eocene) of Seymour Island, Antarctica. Polish polar research, 27 (2), 153-170.
24. Pemberton, S. G. \& Jones, B. (1988). Ichnology of the Pleistocene ironshore formation Grand Cayman Island British West Indies. Journal of Paleontology, 62, 495-505.

25. Uchman, A. (1998). Taxonomy and ethology of flysch trace fossils: revision of the Marian Książkiewicz collection and studies of complementary material. Annales. Societatis Geologorum Poloniae, 68, 105-218.

26. Bromley, R. G. (1990). Trace Fossils: Hayman, U. ed., Biology and Taphonomy, Chapman and Hall, London, p. 280.

27. Pemberton, S. G. \& Frey, R. W. (1982). Ichnological nomenclature and the Palaeophycus-Planolites dilemma. Journal of Paleontology, 56, 843-881.

28. Walker, R. \& James, N. (1992). Facies models: Response to sea level change. Geological Association of Canada, 407.

29. Robert W. Frey, H. Allen Curran \& S. George Pemberton, (1984). Tracemaking activities of crabs and their environmental significance: The Ichnogenus Psilonichnus. Journal of Paleontology, 58 (2), $333-350$. 